\title{
THE FABRICATION OF A JESUITED MOCK WEAL
}

\section{Catholic Reassertions of Englishness}

One of the principal dangers in this subject is to see the struggle as between 'two tightly consolidated blocs, Roman and Protestant.' Binaries were attractive to polemicists but as historians, one is rightly sceptical about their truth-value. There was much contestation both within as well as between Catholic and Protestant factions. As regards the perceptions of national status with which we are concerned, not all Protestants would have felt Catholics to be un-English, especially when social similarities or geographical proximity were such as to override religious divisions. Quite understandably, many Protestants would have had more in common with Catholic neighbours of a similar social standing than they would have had with coreligionists further down or up the social scale. Besides, in a population of 4 million, the 40,000 or so remaining Catholics did not seem so much of a threat. Catholics, for their part, having started to accept minority status from the end of the 1580 os onwards were finding a modus viviendi under the Protestant regime and, some spectacular exceptions aside (the most infamous being the Gunpowder Plot), proved to be moderately successful at adapting in the Jacobean period. ${ }^{2}$ No doubt they continued to see themselves as English despite the prevalent rhetoric of estrangement, but to date, they had not done a convincing job of asserting it in print. At the cusp of the new century, we find evidence of a desire among a sector of the Catholic community to do just that: to recapture lost ground and to reclaim their status as true sons of the nation. Their success was limited. Certainly, they did not manage to reverse the lazy stereotype regarding the innate foreignness of popery, but they did manage to help channel it ever more into an anti-Jesuit direction, thus, to a certain extent, taking the heat off the majority at the expense of a minority. The greatest irony was that, in making a case for loyal English Catholics, they exposed and exacerbated intra-Catholic disunity. This was unfortunate as far as presenting

\footnotetext{
1 Questier 1996, p. 9.

2 Questier 1996, p. 4.
} 
a united front was concerned but altogether inevitable because the only way loyalist Catholics had of escaping the accusation of un-Englishness was to place the blame on the Jesuits and their followers (the Jesuited), all the while insisting on the purity of their own credentials. The Jesuited were readily sacrificed on the altar of the nation.

It was ironic that the proximate occasion should have been the Archpriest controversy from 1598 onwards, for, considering that the appointment of a senior cleric to oversee the English mission was meant to assuage tensions rather than stir them up, it ought not, strictly speaking, have been a controversy at all. Although George Blackwell, the archpriest appointed by Rome, was not himself a Jesuit, his brief to work in close consultation with the superior of the Society in England made it appear to some secular priests and interested onlookers that he was something of a puppet, and they more puppet-like still. Such a state of affairs rankled with many, although not perhaps as many as the pamphlet overflow would lead us to believe. ${ }^{3}$ Added to the news of Persons' reappointment as rector of the English college in Rome in the same year, the whole was seen as an unwarranted Jesuit take-over of the English mission.

Accusations of excessive Jesuit influence have to be balanced against the bare facts: the actual numbers of Jesuits working on the ground in England was very small. In 1593, there were merely 6 ; by 1598 , the number had increased to 14. By 1610, there were 51. At any one time, some would have been in prison. ${ }^{4}$ Still, despite small numbers, they were deemed to have disproportionate influence throughout the period, and the general fear was compounded by the knowledge of the Jesuits' expulsion from France 1594 to 1603 and the speedy translation and publication of French anti-Jesuit texts in England. ${ }^{5}$ Although the Archpriest controversy has a narrowly technical side involving clerics annoyed at the preferment of others, the affair has wider significance in that it afforded an opportunity to some spokesmen for the Catholic community to drive a wedge between the true Catholic English and those tainted with Jesuitism. It is the most striking instance in the whole period of Catholics entering the polemical

3 We do not know how great the split was amongst the seculars on this matter. Most would appear to have accepted the appointment (Pritchard 1979, p. 120), but some of the more vocal ones did not. 33 priests signed the appeal on 17 November 1600.

${ }^{4}$ Foley $1877-83$, vol. 7, lxvi-lxix.

5 See for example the Étienne Pasquier The Iesuite displayed (1594) and The Iesuites Cathechisme (1602), and also Antoine Arnauld The coppie of the Anti-Spaniard (1590), The arrainment of the whole society of Iesuits in France (1594) and Le franc discours A discourse, presented of late to the French King (1602). 
fray and battling to reassert their Englishness not only against consistently negative Protestant propaganda but against what they perceived as the subversive internationalism of the Society of Jesus.

It is the voice of Anthony Copley that stands out most clearly in this endeavour. As a layman, he was freer from the internal clerical wrangling which characterised some of the other interventions. Two works of his are notable. An ansvvere to a letter of a Iesvited gentleman and Another letter of Mr. A.C. to his dis-Iesvited kinseman, published in adjacent years, were framed as private letters, but writings of over a hundred and over eighty pages respectively were so obviously destined for publication from the start that the epistolary exclusivity is merely a veil. ${ }^{6}$ His 'dear cousin' stands in, as it were, for all the deceived Jesuited of England, a cautionary tale for his coreligionists. It is not the least of ironies that the Catholic Copley was responsible for bringing the opprobrious words if not the concepts of 'Jesuitism' and the 'Jesuited' into the printed English language, adding them to the growing body of words to describe a twisted nature. ${ }^{7}$ However, he is marginally more optimistic about conversion: holding out the possibility, from the recovery of his cousin, that even the Jesuited could become properly English again.

What makes Copley's efforts to argue his case all the more creditable is the narrowness of the plank on which he finds himself. What he had to do involved at least three different balancing acts of which he cannot but be acutely aware. First, he wanted to state firmly that Catholic identity could be validly held in conjunction with national allegiance, but in so doing, he had to avoid eulogizing the past, making abrasive comments about the present, or advancing imprudent speculations about the return of the old religion in glory. Secondly, he had to come up with a convincing distinction between the Jesuited English and other English Catholics to replace the prevalent axiom which tended to work against all. At the same time, he was not to make his criticism of them so damning as to leave no possibility for a process of what he inelegantly referred to as dis-Jesuitism. Thirdly, it was out of the question that he would back down on the Roman element of Catholicism, although it was going to be necessary to keep it

6 The second letter comes with a third added on, entitled 'A third letter of Mr A.C. apologeticall for himself against the calumnies contained against him in a certain Jesuiticall libel intituled 'A manifestation of folly and bad spirit' in which he replies to [Persons] 1601.

7 The $O E D$ does acknowledge that the first appearance of 'Jesuited' was in C[opley] 1601. But it sets a latter date for the appearance of Jesuitism, tracing it to Barlow 16og. In fact, it should be dated to the works of Copley and Bagshaw some seven years before. See, for example, C[opley] 1601, p. 39; [Bagshaw] 1601, p. 3. Iesuticall is a word they also use. [Bagshaw] 1601, sig. a4v; C[opley] 1601, pp. 70, 120. 
muted and contained and to explain away the uncomfortable aspects which Protestant writers had relentlessly exposed. He was going to have to find a way of taking the sting out of popery. These were not easy tasks, and his manner of engaging with them shows some ingenuity and a measure of originality.

The way in which he develops his ideas about nature in connection with nation and religion in these texts is one his most effective ways of presenting his case. For a start, it is not human nature that is under sharp focus but a particular application of it, differentiated along national lines. Identification with one's country wells up, he believes from the 'ingenerate law of nature' and thus to go against one's country in any way is not only contra ius gentium but also, he hastens to add, 'vnnaturall, yea and against all grace', that is to say, not just a legal infraction against the conventions but something that contradicts the profound natural logic of being. ${ }^{8}$ So for him, one's true nature is nationally defined, and he goes on to articulate it in a specifically English context. His version of what English nature should entail draws heavily on the Protestant hegemonic vision, for all that he is Catholic. His point is, undoubtedly, that Catholics can share in this too, and that they can be at one with their Protestant countrymen. The most striking feature is the emphasis on liberty. There is a deep repulsion to subjection visible throughout - most of all at the culmination of an intensely lyrical passage glorifying England, when he winds up by considering how 'dishonourable and abominable' it would be to 'true English-nature and valour' to become subject to Spain. ${ }^{9}$ Freedom is emphasised to counteract the axiomatic association between popery and slavery. He is the first Catholic controversialist to insist on breaking apart the association, and therefore, one might conclude, the only one who took it seriously enough in the first place. Indeed, it is in his text that we find the most idiosyncratic analogies on the subject. It is unthinkable 'as hitherto England hath bin selfely substantiue so it scorne to become now an adjectiue, much more subiectiue to Spaine or anie other nation in the world'. ${ }^{10}$ So also Englishmen, as independent stand-alone 'nouns', cannot consent to lower themselves to merely adjectival status: the English Spaniard is a grammatical barbarity as well as a moral oxymoron. The theme recurs in a less poetic way in his 1602 letter where he says that it is incumbent upon the Queen to ensure that England 'subsist of its selfe

\footnotetext{
$8 \mathrm{C}$ [opley] 16o1, pp. 11, 40.

9 C[opley] 16o1, p. 48.

10 C[opley] 16o1, p. 73.
} 
secure and English [...] without being beholding..11 We recall that this is precisely the language that has been used repeatedly to describe the unnatural behaviour of Catholics in other polemical works. Here, he deliberately appropriates the same idiom and insists on sharing this common ground with Protestants.

Furthermore, he clearly wants to show that loyal English Catholics share the same prejudices and antipathies towards the ways of being of their national enemies as their Protestant countrymen. '[W]e' as Englishmen would never be able to abide Spanish humours and fashions'. ${ }^{12}$ It is a simple statement but highly revealing. Copley, it would appear, wants to shrug off the constant corrosive cultural associations that Protestant writers have created between English Catholics and Spaniards, in a language which portrayed the former as being infected by Hispanic humours. We note, en passant, that what Persons refused to do (i.e. buy into stereotyping), Copley does with great gusto, having no particular intellectual scruples on the matter.

Another way in which he makes his case is to argue on the basis of numbers that the vast majority of English Catholics are truly English. It is a reaction to the exaggerated view that in every Papist heart there lurked a traitor in potential. There are, he claims, 40,00o Catholics in the country. Out of these, most are peaceable, and this meant that 'England hath as true English-Catholickes in it, as it hath Catholicke-English'. ${ }^{13}$ He reverses the terms rather pertly: it is all one. Neither one takes precedence over the other. How to explain away the fact that the plots do tend to come from Catholics? Copley has a neat reply ready. If they are not loyally English, then they are not properly Catholic either: they have been Jesuited. This is his way of turning the aggressive anti-Catholic rhetoric away from the body as a whole and towards a limb that he thinks easy to amputate. These confident statements about the Englishness of Catholics have also to be seen against the background of rather more ambiguous sentiments. He evidently felt an urgent need to remind his co-religionists of their fundamental duties: 'euer let vs that are true Catholikes perseuer as we are and ought no lesse true English'. ${ }^{14}$ The letters are injunctions rather than commentaries.

11 C [opley] 1602, p. 44.

12 C[opley] 1602, p. 17.

13 C[opley] 1601, pp. 98-99. We cannot be certain of the figure, given the spectrum-like nature of religious affiliation especially in penal times, but his estimate seems fairly accurate, according to modern data. By 1640, the number may have risen to 60,000. Bossy 1975, pp. $188,193$.

14 C[opley] 16o2, p. 44. 
Personally, he expressed his comfort in the compatibility of his dual identity which rested 'vpon true-Catholicke and English loyaltie'. ${ }^{15} \mathrm{He}$ had previously stated that he was prepared to go to any length of mortification rather than give up on this: 'rather then be so vn-Catholicke and vnEnglish, I protest I had rather neuer eate bit of fish or flesh whiles I liue'. ${ }^{16}$ Even more emphatically, he advanced the view, radical in its way, that to be Catholic was actually to be more English, not less: 'let vs remember we are Englishmen, and also Catholicks, whereby bound to be the rather true English ${ }^{17}{ }^{17} \mathrm{He}$ repeats this the following year, saying that 'it were a maruell if Englishmen, especially Catholickes, who (as such) ought to be the best and loyallest subiects'. ${ }^{18}$ Why does he advocate that Catholics show themselves to be more English than other English people? Two reasons may be inferred. Firstly, being true to one's nation is in keeping with religious truths and these a Catholic should respect more than anybody else. Secondly, it is his way of saying that his co-religionists need to prove their critics wrong: they themselves must restore their own image and standing after the contestations of recent decades. This is an entirely new idea. Of course, in the subsequent history of English Catholics, particularly upper class ones, their cultivated sense of 'Englishness' has indeed been remarkable, proved, not least, after the passage of William Pitt's relief bill in the 1790 , by their disproportionate presence in the armed forces of the country and shown in their consistent (and, at times, dramatic) lack of solidarity with Irish Catholics (seen as being irredeemably other). The 'Cisalpine' rather than the 'Ultramontane' spirit has also been a feature of the minority community, as they stayed aloof from Rome as much as possible, so as to avoid accusations of excesses of papistry. One historian of the subject has indeed affirmed that a 'line of spiritual descent' [...] can be traced from the lay opponents of the Jesuits in the sixteenth century through the supporters of the oath of allegiance under James I' to the Cisalpine English Catholics of the eighteenth and nineteenth century. ${ }^{19}$ However, this may be, in the early 16oos, Copley's is the first call in print for Catholics to be more loyal to the present regime, its government and its liberties than their Protestant counterparts. It is a plea for Catholics to become more English than the Protestants. They have something to prove.

15 C[opley] 1601, p. 118.

16 C[opley] 1601, p. 74.

17 C[opley] 16o1, p. 73. My italics.

18 C[opley] 1602, pp. 15, 17.

19 Mathew 1936, p. 148. 
The allegiance of priests in particular was, inevitably, an issue, and Copley would go out of his way to endorse the secular priests of whom there were several hundred in England at that time. He insisted that they alone were the 'naturall broode of our English Church', and that they possessed 'pure English nature and allegeance'. ${ }^{20}$ They were not spies for Rome. Copley does not sidestep an awkward issue: in the 1580 s, it was they who had welcomed the Jesuits in the first instance. How is Copley going to get around this? The argument that he makes in their regard shows some astuteness. He cannot deny the fact but he does mitigate the blame accorded to them. His summation of the episode is that, although it was surely a faux pas, it was a comprehensible one, born of naïveté rather than malice. Furthermore, even their defects are mitigated by the fact that they are not peculiar to them as a class of men but lamentably common to the whole nation.

They like simple-ciuill English-men doing them [the Jesuits] at the beginning all the honour that might be, whereby to bring them (being straungers) in acquaintance with our Countrey [...] have wrought them such an existimation, as now (we see) cuts their throates, through their vngratefull making use of such their curtesies against them. ${ }^{21}$

There are a number of features evident here. Firstly, the guilelessness of the English priests is a backhanded compliment: even though it has led them astray in this case, it is surely to be preferred to all the 'cosining constructions' of the Jesuits. ${ }^{22}$ Besides, it has resonances of plainness and sincerity on which so many of his contemporaries set so high a value. Also notable is the reference to their simple and honest civility, an implicit contrast to the Jesuits' false gallantry. Secondly, we note that he talks of the early Jesuit arrivals as 'strangers'. This is untrue. They were all Englishmen, but his point is that they had been made into foreigners by their sojourns abroad. Subsequent efforts made by the seculars to convert them back to native ways were doomed to failure, eliciting only a response of rank ingratitude. Crucially, his perspective widens at this point, and instead of holding the seculars responsible, he shifts the blame from the seculars to the nation at large, saying 'And so vaine a Nation are we, and euer were, to praise outlandish wares though less good (nay bad) aboue

${ }^{20}$ C [opley] 1601, p. 19; C [opley] 1602, p. 44. He calls the seculars the seminary priests. The remaining Marian priests would not have been under the surveillance of the Archpriest. See Pritchard 1979, p. 120.

21 C[opley] 16o1, p. 37.

22 C[opley] 1601, p. 84. 
our owne'.23 In other words, this is just one incident of many, and much of a colour with the national penchant for the strange, the unfortunate habit of looking abroad rather than within for things of value. So Catholic priests are not exceptional in being 'taken in' by outlandish imports. They have been cozened but then again, so has everybody. Catholic secular priests are 'English' even in their weaknesses. It is the old story, familiar through study of the Elizabethan cultural commentaries, of imitation: lamentable, of course, but not exclusively a Popish fault.

Probing his attitude to the Jesuits somewhat more requires engagement with a loaded question, uttered a little over half-way through A letter. He asks if 'these men [are] either Catholicks or true Englishmen'. ${ }^{24}$ It is a question that elicits a strong negative, and that, not just in the face of the conventional evidence he marshals, but in the face of the language he uses so powerfully to amputate them from any sense of either. He voices the usual critique - from the impertinence of the Society's name to their vainglory, but the two points which really stand out as interesting are when he treats of them as aliens and as ubiquitaries. Naturally, he will say that he is merely showing up how they have constructed themselves and that he is describing the reality rather than judging them from a sense of 'private grudge'. ${ }^{25}$ The Jesuits, he maintains, are 'construing themselues verissimè alienos afore all others' and all the worse here in England where they are 'aliens from all English-nature, Spanish-aliens, aliens to all that is called English saue onlie English monie'. ${ }^{26}$ What does it mean to construe oneself? In this text, it evidently means exactly the reverse of letting one's true nature emerge. It is an artificial activity of self-fashioning, selffabrication even. The only 'English' item in their make-up is something that they take by stealth: English money, an imputation that they are financially insatiable and dependent on the grace and favour of the great, a common imputation against the Society.

The other resonant way in which he seeks to divorce Jesuitism from Englishness is by talking about its clerics as 'Vbiquitaries', that is to say people who gave the impression of being everywhere at once. Copley is extremely critical of their habits as 'indiuidua vaga and vndependant of any bodie at al'. ${ }^{27}$ Somewhat ironically, the Jesuits are commonly pictured at both extremes of individualism and communality, dependence and

${ }^{23}$ C [opley] 16o1, p. 37.

${ }^{24} \mathrm{C}$ [opley] 1601, p. 90.

25 C[opley] 16o2, p. 61 (3rd letter).

${ }^{26}$ C[opley] 16o1, p. 84.

27 C[opley] 1601, pp. 27, 118. 
independence. Sometimes they are depicted as an army on the move, none of them having any will of their own, but for Copley, they are wandering, aimless individuals, roaming the world intent on mischief. Moreover, he stresses their negative independence, that is to say their freedom of proper attachments and of the right sorts of bonds rather than the more commonly-mentioned slavish dependence at this point. If we are to tease out Copley's hostility towards cosmopolitanism somewhat more, we could say that the state of being ubiquitous, for him, denotes pejoratively what Catholicism denotes positively. Rootlessness was the converse of an authentic universality, and the shifting Machiavellian lifestyle often attributed to the Society flourished in such mobile conditions. Thus its members, lacking the bonds which would tie them to any civil society except their own, cannot be accommodated in this layman's vision of what ought to constitute a stable national community. Such men have excluded themselves from communion in the nation: 'What will ye haue of Vbiquitaries' he asks rhetorically 'other then mis-nature, or rather no nature at all?'28 The concept of misnature is worth dwelling upon; he had mentioned it before in the letter. ${ }^{29}$ Misnature is a perversion of the essence of one's being; indeed, to employ the analogy of the journey, which is very much in keeping with his ideas about ubiquity, it is as if the Jesuits have turned nature off course. In talking of their having no nature at all as he does at this point, he takes this idea one step further. English Jesuits are unnatural not just in the weaker sense that they are national anomalies but in the much stronger sense that they are completely cut off, that their nature has been uprooted rather than simply derouted. This is because, he goes on to say, such ubiquitaries 'neuer hauing of their owne nation, but of a stranger ouer them, whereby to be directed Englishly'. ${ }^{30}$ The last fraction of the phrase may be understood a reference to the fact that their actions are being directed from outside towards England, but crucially not in an English manner. They are only true to the rule of strangers.

If the Jesuits are aliens and ubiquitaries, they are also akin to fallen man. They have spread sin, but national as well as moral sin. That English nature should be 'so stained' by the English Jesuits and Jesuited is a most shameful thing, the inference being that as they gain more and more into the 'hearts of Englishmen' (as he says they are), national nature will be increasingly scarred and distorted. To underscore his argument, there is

28 C[opley] 1601, p. 118.

29 C[opley] 1601, p. 65.

$30 \mathrm{C}$ [opley] 1601, p. 118. The irony of this is that Copley himself after his exile travelled to Jerusalem, and then to Brussels, Rome and The Hague. 
an extraordinary nationalistic usage of Thomistic theology at this point. Aquinas, in a celebrated phrase, had said that grace does not destroy but build upon nature. Copley twists this idea to his own ends: 'A shame that Religion should be so profaned, or English nature so stained: grace neuer vsing to preuaricate nature but to accomplish it'. ${ }^{31}$ The use to which it is put here is novel and not at all what Aquinas had in mind but Copley is keen to appropriate the authoritative moral theological language in the Catholic tradition so as to make his point more substantial.

This makes it very interesting indeed. For Copley, nature is to be understood as one's national properties and allegiances: that is all. Aquinas was talking about an unrestricted humanitas, which was emphatically not delimited by nation, nor by religion for that matter. Now Copley's thesis is that the Jesuited have got it wrong both ways. They manifest a 'mis-nature', and also, one could say, a spiritual dis-grace. If we draw his thought beyond the point where he is explicit, we see that, just as nature is the ground and grace is the edifice, he presents his case on the basis that one's fundamental identity is national, and that religious loyalty, although no less important, is superimposed. The English Jesuits, in abandoning the foundations of who they are, are building upon sand. Nevertheless, and this is what makes Copley a reasonably buoyant commentator on the state of affairs, he still holds out the possibility of such recalcitrants dis-Jesuiting themselves. Unlike some of the Protestant propagandists, degeneration was, to his mind, reversible to some extent. ${ }^{32}$

If Jesuits were problematic for Copley's vision of Englishness, what about Rome? How does he try to neutralise its problematic status in late Elizabethan England? Rome is there in the background, sotto voce as it were, to the main theme. Maybe his frequent usage of the word Christendom is a way of de-emphasising the foreign element of it all. When he does refer to the Pope, his role is considered uniquely as it affects Englishmen. The Bull of 1570 was inconsiderable in that it left 'English hearts' intact, not 'disallegeanced so from her Maiestie' because it did not implicate any foreign powers. He wilfully ignores the generally received interpretation of this episode. Besides, as he explains later, Catholics ought not to feel compelled to obey Papal Bulls that come from the pope

31 C [opley] 1601, p. 39. Aquinas 1963, I, p. 30, Prima Pars Q1 a.8, ad. 2. '[G]ratia non tollat naturam, sed perficiat'. This indicates that he had some theological education. He spent two years each in Rouen and Rome, including a year and a half in the English college in the latter. According to Persons he was going to become a priest, a claim which he flatly denied. C[opley] 16o2, pp. 52-4 (3rd letter).

32 C[opley] 1601, p. 70; C[opley] 1602, p. 44. 
as men, not as popes. ${ }^{33}$ This position is a little semantic, it must be confessed, but necessary to allay Protestant fears that Catholics must obey everything imposed from above. The Roman dimension is anodyne, unthreatening: it is not the supranational power competing for the hearts of Englishmen. It is an essentially religious authority and its political role is relegated to the background. The loyal Catholic can be Roman (if not Papist) and English at one and the same time.

Yet in softening down references to Rome, he does not altogether drop the idea of the reconversion of England to the old faith. His vision of the future combines both trusting abandonment and a resolute nationalist imperative, the former because of his providentialism, the latter because, whatever happens, he stresses that it is necessary to do everything in an English way. Any change, in other words, must be the result of an internal process not outside interference. For a Catholic writer of the time, there is an unusual degree of laissez-aller in the statement 'why not let England continue English, and worke itself Catholicke againe (if it please God) in English manner?'34 We are far removed here from the activist rhetoric of Persons and other robustly assertive Catholic restorationists. Copley later expanded on the idea of a national way forward, citing the need to look within for true solutions to their own problems. 'If we our selues within our selues banisht religion, why may not we our selues within our selues bring it in againe?'35 The conversion of England is, for Copley, an entirely domestic affair, and has to remain so. If the situation is to change back, it will be a gradual and organic process, involving no international histrionics. Moreover he is prudent enough to recognise that even if things do not radically revert to old ways, the toleration for which Catholics hope in 1601 must be achieved within this frame and that they must avoid bringing to bear outside pressure on national policy. 'And far more Catholicke, and farre more naturall it is, to hope one day to be beholding to our owne State for Catholicke libertie, then to a forraine, with so desperate conditions and against all religion. ${ }^{36}$ The future, as he repeatedly brings out is in God's hands, especially as regards the conversion of the Queen. ${ }^{37}$ Yet there is a clear imperative for the present which he announces, in clarion tones,

33 C[opley] 1601, p. 48; C[opley] 1602, p. 41; C[opley] 1601, p. 39; C [opley] 1601, p. 73.

34 C[opley] 16o1, p. 54.

35 C[opley] 1601, p. 66.

${ }^{36} \mathrm{C}$ [opley] 16o1, p. 66. There is an oblique plea in the 1602 letter, p. 44 where he says at the very end, 'Neuerthelesse it may be that casting downe by chance her Queenely eye vpon these our Appellant fathers, and vs their childrens thus loyall cariage to her State, she will in time be pleased to be less heauie Princesse vnto vs, if not indulgent'.

37 C[opley] 16o2, p. 44. 
at the culminating point of his first letter. 'Stand we [...] that are Englands vpon English, and let all forraine rule goe by'. ${ }^{38}$ In sum, Copley's letters are a first attempt in print to make Catholicism compatible with Englishness again. Against the pervasively stigmatising discourse, against the popular stereotypes of Popery, Copley sought to do battle. No doubt, in so doing, he expressed what many inarticulate loyalists had felt over many decades. That he makes his case at the expense of the Jesuits and those who follow them was inevitable. There was only one prejudice that was stronger and more capacious than anti-popery and that was anti-jesuitism.

Another voice that made similar claims at the time of the Archpriest dilemma was that of Thomas Bluet in his 1601 work entitled Important considerations, which ought to moue all true and sound Catholikes, who are not wholly Iesuited. In the disproportionately long preface, he stresses how urgent a task it is for his co-religionists who are not wholly Iesuited to present a coherent front. He addresses his readers 'as you are Catholike' and also in the same breadth 'as you are English'; and again as 'Catholikes and English, or if you please English Catholikes'. Like Copley, English identity is seen as natural, Catholic identity supernatural and both are inherently complementary. ${ }^{39} \mathrm{He}$ enjoins his co-religionists to live up to their double duty: 'yet were we all bound by our Catholike profession [...] by our loyal naturall English affection: to haue opposed our sleues to the Iesuiticall or Spanish faction' ${ }^{40}$ He warns them that if they do turn traitors, they will be despised and despoiled.

Neuer shall any Prince, people, or nation point at us: for traitors, unnaturall Englishmen: laugh us to scorne [...]: after they haue had the sacke and spoyle of our countrey by our meanes. ${ }^{41}$

He also integrates the popular Jesuitophobic rhetoric of Protestants: the 'forreine Iesuiticall practises' are contrasted in the Considerations with innately English activities. ${ }^{42}$ All the usual accusations from 'unnatural designments', to 'bondage', 'inueigling', inticements' and indeed the attempts to overthrow this 'flourishing common wealth' are in evidence. It would be hard to find a Protestant text more completely saturated in this idiom. He specifies that the Jesuits are 'Hispaniated, and transported in

38 C[opley] 16o1, p. 65.

39 Bluet $1601,{ }^{*} 2{ }^{*}{ }^{*}$ v

40 Bluet $1601,{ }^{* *} 2$.

41 Bluet 1601 , sig. $\mathrm{A}^{\mathrm{v}}$.

42 Bluet 1601, p. 28. 
those humours the better to resemble and imitate their founder'. ${ }^{43}$ It is a small point but an important one that the Englishman is regarded as having a 'nature' and the Spaniard merely 'humours'. The former demanded reverence in seventeenth-century thought: there was a fixed innateness about its workings in man, even if it did not, unfortunately, guarantee inviolability. The notion of a humour had acquired the connotation of irrationality by the early 1600 s and it is this that both Copley and Bluet seem to be playing on. ${ }^{44}$

Another very important part of what Bluet seeks to do, like Copley, is to restore the national credibility of secular priests (of which body he forms part). In contending that they were the real 'fathers' of the English mission, he says that it is not primarily because they are holier, although he does later imply this by saying that they have more martyrs, but because they are truly English 'naturall English subiects [...] unfeinedly vowed friends by birth, bloud, education, affection, religion and all motiues'. ${ }^{45}$ These motives are reaffirmed by their behaviour, which is, as he later points out, characterised, unsurprisingly, by 'plaine dealing'. ${ }^{46}$ What we find in Bluet is an impassioned appeal to English Catholics to side with true English priests and not to stain their 'English innate loyaltie, with Jesuiticall conspiracie of a Spanish invasion.' If they do take the other side, he makes no secret of it that the 'present state' would 'cut you off and also that they would bring down upon the whole nation the most disastrous kind of ruin. In an extraordinarily rapt piece of prose, he declares that never shall any such fate befall England through the means of loyal secular priests. Two examples of his poetic defence of Englishness will suffice. Never shall 'Noble or Generous hart be puld down nor their ancient inheritance, $[\ldots]$ and patrimony' be taken from them 'by our procurement' and never shall the 'Vermilion blush of English virgins' 'be profited and made common to the abortives of the hote Spanish clime by our doing'. ${ }^{47}$ All the staple features of the leyenda negra are there: the innocent English pitted against the seducing Spaniard. It is only novel because of its Catholic provenance.

The third Catholic text which seeks to remove the 'stain' of Jesuitism from English Catholicism is Christopher Bagshaw's A sparing discoverie of our English Jesuits. This is an exhortation 'unto all true English hearted

\footnotetext{
43 Bluet 1601, p. 42.

44 Bluet $1601,{ }^{* *} 3,{ }^{* *} 3^{\mathrm{v}},{ }^{* *} 2^{\mathrm{v}}$, OED sub humour.

45 Bluet $1601,{ }^{* *} 2 \mathrm{v}$.

46 Bluet 16o1, p. 4.

47 Bluet 1601, sigs. A2-A3.
} 
Catholickes' to beware the 'Iesuiticall poyson' ${ }^{48}$ There may be marginally more compromise here for he does concede that the Order in itself is to be honoured, having been approved by the Pope. Nevertheless, as few people live according to their calling, he can inculpate them at will. ${ }^{49}$ If there is a certain ambivalence here, it is not in his interest to acknowledge it further, and throughout he rehearses the traditional critique of their politiquing, meddling, ambition and dubious forms of spirituality, all perhaps best summed up in the reference to the ensemble of 'Machiavellian practises,' cue, it seems, for an authorial shudder. ${ }^{50}$ Crucially, he believes that no Jesuit retains his original birth-right; the 'Inuentor of their order being a Spaniard [...] of what country soeuer any [...] are by their birth; in their hearts and practises they are altogether Spanish. ${ }^{.51}$ It is a phrase that Thomas Bell would go on to quote triumphantly a year later, his implication being that if Catholic priests think that a Jesuit cannot be English, then the matter is all the more clear: they have incriminated their own confrères. ${ }^{52}$ It is this axiom in any case that for Bagshaw is hors de question. Whilst he admits that some Jesuits may be good men, he adds immediately 'I doubt those are not Engl[ish]'. Not content with being aliens themselves, they were always trying to alienate the minds of Englishmen. ${ }^{53}$

All adds up to the fact that one cannot be both a Jesuit and truly English at one time. Nor does he allow for people to 'dis-Jesuit' themselves as Copley had done. Indeed, there almost seems no hope for them; at the very end he sketches out a demonic chain of command, where the Archpriest Blackwell looks to Henry Garnett who looks to Persons who in turn looks to the devil. ${ }^{44}$ But as we have established, such polemic ranges from the profound to the casual; if the demonic is at one end of a scale, the reference to their 'Hispanicall conceits' is at the other. ${ }^{55}$ The usage here is on a par, in a sense, with the idea of humours which we have previously had occasion to investigate; ${ }^{56}$ its vanity invites irreverence, its strangeness contempt. Certainly, Bagshaw is divided between taking the threat seriously and thus fearing it as devilish, and taking it lightly and mocking it. Perhaps the implication is, like it was in Bluet's Important Considerations,

\footnotetext{
48 Bagshaw 1601, sig. a4v

49 Bagshaw 1601, pp. 6-7.

50 Bagshaw 16o1, pp. 6, 7, 16-17, 21, 23-4, 28, 6, a2.

51 Bagshaw 1601, p. 7 .

52 See below p. 185 .

53 Bagshaw 1601, sig. a2.

54 Bagshaw 1601, p. 70.

55 Bagshaw 1601, p. 3.

56 See above pp. 164, 171, 179.
} 
that the truly English have integrated identities - he does use this concept of integrity when ironizing on Persons' lack of it ${ }^{57}$ - while the Hispanicised English have mere 'conceits'. If so, this would tie in very properly with the rather turgid opening image of a picture of Venus, painted so as to please the eye yet in reality concealing the person of a strumpet, a 'common queane'. In the same way as all her perfection was merely 'complementall', so the English Jesuits too have superficial conceits which pass for nature, but are in reality unnatural foreign accretions, purposefully misleading. Bagshaw is insistent that they are counterfeit Englishmen intent on bringing in a 'mock-weale', an utter inversion of the true order in church and state. This mock-weal will be characterised by despotism and oligarchical power because the Jesuits know well how to refine a Monarchie into the form of a Prouince.' Like Copley, Bagshaw also makes the most of the motif of the freedom-loving true Catholic Englishman. When he is depicting the havoc that Jesuits would inflict on England, he does not merely mention the danger to the privileges of the higher orders but also the dangers to the 'free holder and Tenant in fee simple of all degrees'. Everybody would suffer. He ends with the sardonic Latin tag: 'A Machinationibus Parsoni, libera nos Domine'. ${ }^{58}$

Catholic polemics during the Archpriest controversy fracture the straight-line of the story and make it much thicker and more interesting. No longer was it just a matter of Protestants accusing Catholics of being un-English; now Catholics weighed in on the debate and boldly reasserted their national credentials and accused their Jesuited brethren instead. Although, as Questier points out for a later instance of intra-Catholic disagreement, these 'spats and disputes do generally look rather pernickety and tedious', they were in fact one of the 'central processes by which Catholicism in England was identified, defined and redefined. ${ }^{59}$ How successful were they? That is indeed a rather more difficult question to answer. It is true to say that anti-Catholicism was becoming more and more fixed in the groove of anti-Jesuitism in the 16oos, and undoubtedly such texts had their part to play in this development (we have seen how they were responsible for inventing/importing what would become conventional words to deride the order). Nevertheless, it is also possible that the increasingly prevalent identification of Jesuitism with un-Englishness would have happened without such interventions as Copley's, Bagshaw's

57 Bagshaw 1601, p. 39.

58 Bagshaw 1601, sigs. $\mathrm{A}_{3}, \mathrm{~A}_{3}^{\mathrm{v}}, \mathrm{a2}^{\mathrm{r}}$, a2 ${ }^{\mathrm{v}}$, p. 70.

59 Questier 2005, p. 7. 
and Bluet's. Marotti comments on the fear caused by the increasing numbers of Jesuits in the country: the mission would be 106-strong by 1620 and 180 twenty years later. ${ }^{60}$ So context alone would have contributed towards an increasing tide of hostility. Perhaps then the real measure of the success of anti-Jesuit Catholic polemic in the early 1600 is its impact on loyalist Catholics themselves to whom it was, after all, primarily addressed. They now had champions in print and more reason for drawing distinctions between themselves and a more Romanist, less authentically national element in their community. There was nothing as comforting as the neuroticism of fine discriminations: to readjust the line between the dutiful and the subversive so that they were unquestionably on the right side was useful if they desired to reintegrate fully.

As regards the print response to Catholic anti-Jesuitism, two texts in particular are noteworthy, representing both the Jesuit self-defence and a Protestant interjection. Persons was, as ever, a rogue controversialist and in A manifestation of the great folly and bad spirit of certayne in England calling themselues secular priestes, he playfully turned the tables on his opponents, undercutting their own boasts of English nature by talking about their humours. Anybody who has read their works, he says, has received thereby a very 'strange opinion of English mens humors, when they are in passion.' Folly, indiscretion, exaggerated language: Persons' accusations show a wearied controversialist dealing with people who are, intellectually, beneath him. ${ }^{61}$ Furthermore, he takes the time to quote entire the wordy passage of Bluet's opening and says that it is not entirely without merit.

All dearly affected [...], as wel for gyfts of graces giuen you, as you are Catholike [...] as also for the gifts of nature giuen you as you are English [...] giue me leaue by an epistle pathetical in one general passage to speake vnto you all alike, in two adoptive surnames, Catholike and English. ${ }^{62}$

However, he observes that his subsequent fulminations against Jesuits and the archpriest show him as lacking in wisdom and some of the virtues befitting a Christian Catholic. It is rather sly, but as previously, we note that Persons never enters controversies with the desire to 'soothe' the plain-speaking, plain-dealing Englishman. He is never arguing on a 'national' platform at all. The unJesuited Catholics had cornered the rhetoric of Englishness.

\footnotetext{
60 Marotti 1999, p. 14.

61 Person 1602, p. 1.

62 Persons 16o2, p. 19.
} 
As for what the established authorities made of the Archpriest controversy, much of that was made evident by the new wave of legislation in 5 November 1602. They accepted the sliding scale of Englishness after their own fashion: the Jesuits were given 30 days to leave the country, the others a more generous allowance of 3 months. It was on the whole a rather poor consolation. As for the reaction among Protestant polemicists, it is to that, in the voice of Bell, that we shall now turn. He brings a distinctive perspective to bear on such issues: having abandoned the Roman Catholic secular priesthood in the 1590s, he had comfortably found his way into a government pension, meted out on the understanding that he would use his inside knowledge to attack the old religion. After the spate of fierce internecine Catholic disagreements of the early 16oos, there was no one more fitting to remind 'all true hearted English subiects' of the lessons to be learned. ${ }^{63}$ These lessons were all the more important given the context of succession in which he wrote. James' mother was Catholic and he himself, although Protestant, was an unknown quantity. This succession was not a subdued affair but very much in the public domain: there were many voices eager to inform the Scottish king of whom he was dealing with and of how things were done in the south. This kind of principle seems to be acting on Bell in The Anatomie of Popish Tyrannie. Standing out from the conventional epistle dedicatorie, there is a eulogy commemorating Elizabeth and hailing James, in the course of which he reassures Englishmen and defines the King's mission along papophobic lines with the words:

Yet English hearts be not dismaide,

King Iames is our regent

Hence Poperie certes he will supplant. ${ }^{64}$

Thus the new monarch is required to fit in with the existing expectations of English hearts, rather than the other way around. The monarch is the incomer, an important bulwark against Popish tyranny, it is true, yet it is Englishmen who constitute the true point of stability against whose expectations and principles he must measure all his actions. It is noteworthy, at the same time, that his message of reassurance is for English not for British hearts. Indeed, there is little consciousness here of the effects of the Union of the Crowns. ${ }^{65}$

63 Bell 1603 , fo. $4^{\mathrm{v}}$.

64 Bell 1603 , sig. A2 ${ }^{\mathrm{r}}$.

65 There is one exception: Bell 1603 , sig. $\mathrm{A}_{3}{ }^{\mathrm{r}}$, where he says that the overthrow or conversion of Papists will lead to the 'comfort of all his true hearted subiects, English, Scottish, and Irish'. References to Britain never becomes a motif in the way that the English dimension does. 
There is nothing outstandingly original in Bell's understanding of what it is to have a national nature. For him, 'true English natures' are measured by the traditional combination of loyalty and affection to monarch and country, as well as the requisite determination to give strangers a wide berth. Papists have excluded themselves from this, and thus should not expect any legislative tolerance. He is mystified that

Disloyall papists still presume,

A tollerate to craue. ${ }^{66}$

He is able to assume a bland union of sentiment among the true-hearted when faced with the recent intra-Catholic divisions. An enemy's confusion must always be pleasing. 'Hence proceedeth that rare conceiued ioy, which hath enuironed me on euerie side. And which (I am well assured,) cannot but bring great contentment to your Lordship, and to all true hearted English subiects'. By 1606, when he came to writing The Popes Funerall, this sentiment of antipathy was still more emphatic. His wish that Papists might be 'stricken dead' came with the corollary that truehearted English subjects would receive 'unspeakable endlesse comfort' from the fact. ${ }^{67}$ The old prejudice was very much alive.

Yet, although Bell expresses a generic anti-Popery in these ways, his particular focus is on the Jesuits and the Jesuited. Bell's stance on them is partly explained by the fact that in former days he was a secular priest and so would have shared the traditional animus towards the upstart Society. ${ }^{68}$ But he is also reflecting the wider trend whereby anti-popish sentiment was being channelled into anti-Jesuitism. However much attitudes might relax to law-abiding Catholics (and there is a visible relaxation under the Stuarts), attitudes to the Jesuits would remain intransigently hostile. He was quick, we notice, to have picked up the word 'Iesuited' from Copley, using it to tar a whole sector of Catholics, lay as well as clerical. This is what he does right from the title page, announcing a 'plaine declaration and Christian censure' and battling against 'English hispanized Iesuites and their 'Iesuited Arch-priest'. The tone is quite venomous. ${ }^{69}$ Indeed, there is an explosion of far-fetched vocabulary. In the preface to the gentle reader, the enemies are again singled out, this time as 'Englist [sic]

66 Bell 1603 , p. 64, sig. A2v

67 Bell $1603,92^{\mathrm{v}}$. The lordship in question is the Bishop of Durham to whom the work is dedicated. Bell 1606 , sigs. $\mathrm{A}_{5}^{\mathrm{r}}-\mathrm{A}_{5}^{\mathrm{v}}$.

${ }^{68}$ He grudgingly admits that there is a 'better sort' of secular priest but not a better sort of Jesuit. Bell 1603, p. 81, sig. B1 .

69 Bell 1603 , Title page. 
Spaniolized Iesuites with all Iesuited popelings ' ${ }^{70}$ The word popeling has echoes of hireling, with all that this implied of subservience. These are preposterous collocations indeed - as preposterous as the realities they are meant to describe. Neither he nor anyone who thought like this was likely to be convinced by Richard Smith's counterargument in An Answer to Thomas Bels late Challeng that the foreignness of the Pope was actually an advantage when it came to internal English affairs, because he would deal in the manner of a 'stranger dispassionatly'. ${ }^{71}$ One's national allegiance was not fit matter for dispassionate analysis. The heart should be engaged and partisan.

In a subsequent pamphlet, The downfall of popery: proposed by way of a new challenge to all the English Jesuits and Jesuited or Italianized papists, the Hispanic taint gave way to the Italianate when the matter was more doctrinal. ${ }^{72}$ In both cases, with the turning of the adjective into a pejorative form (-ized), he wanted to mimic the ugly reality of those who have turned their English natures into something else, something less. This sweeping challenge echoes through his works, and one of the effects of the repetition ad nauseam is that, in much the same way that Anthony's insidious insistence on Brutus' honour in Shakespeare's Julius Caesar leads us to doubt its veracity, Bell's challenge to the English Jesuits and Jesuited Papists makes us entirely sceptical of their credibility as Englishmen at all. ${ }^{73}$

The greatest irony (for the Catholics of Copley's ilk) in Bell's polemic was the way he exploited what they had to say about the Jesuits, but never gave any endorsement to their earnest declarations of loyalty and true allegiance. He was simply not interested in defending the Englishness of some Catholics; his burden was to alienate them all. The fact that the Society had been condemned by co-religionists only added strength to his argument. It is in the way of being his trump card. He directs his readers' attention, for example, to the part in Copley's An answvere to a letter of a Iesvited gentleman, where he had excluded the Jesuits from possession of true Catholic religion and 'true English nature and valure'. ${ }^{74}$ Bell adds a 'marke well this lesson' in the margin at this point, a didactic nudge: his readers need only concern themselves with the appropriate lessons to be drawn from that particular controversy. We have already seen how Bell quotes triumphantly Bagshaw's damning statement about the foreignness

70 Bell 1603 , sig. $\mathrm{A}^{\mathrm{r}}$.

71 Smith 1605 , p. 20.

72 Bell 1604, Title Page.

73 See, for example, Bell 1605, p. 22; Bell 16o6, sig. E3 ${ }^{\mathrm{r}}$.

74 Bell 1603, p. 21. Quoting C[opley] 1601, p. 70. 
of Jesuits. They stood incriminated by their own: this is enough for him to prove that the whole community of popery represents 'troubles, cruelties and garboyles.'. ${ }^{75}$

Although much of his thinking is fairly crude diatribe, he does articulate a concept of 'formalism' which is of some interest. He has evidently been much struck by the comment of a Scottish Jesuit, Alexander Hays who, 'out of the abundance of his heart', is credited with having spoken the following words: 'Hitherto [...] we haue beene Spayniards, but now we are constrained to be French. It is all one, we must formalize until a fitter season'. ${ }^{76}$ In short, what they are being told to do when on mission is to temporise, make shift, and play parts as convenient for the time being. Bell finds this chameleon-like behaviour altogether unacceptable: they 'will be Spaniards, or Frenchmen, or whatsoever else, if opportunities be offered thereunto'. They take on the form of something else but have no substance to back it up. The idea of the Jesuits being archetypes of formalism is of a piece with the idea that they were courtiers, a view that he had already expressed. It also tallied with the accusation of colour-changing. Members of the Society, he said, 'varie their colours like the Camelion'. ${ }^{77}$ This was not just a reference to the Jesuits usage of multiple disguises to help them pass unnoticed in dangerous territory. It was also an accusation that their identity was contingent on circumstances.

Accusations of formalism have a particular resonance in relation to language and rhetoric. One of the most notorious controversies of the era was that surrounding equivocation and mental reservation. Equivocation had first come to prominence in an English context in the trial of Robert Southwell in 1595 and was even then criticised by Sir Edward Coke. Henry Garnett wrote $A$ Treatise of Equivocation in the same year, stating the uses and limitations of the practice but it remained unpublished. The issue was to become ever more problematic in the 1606 trial of the Gunpowder Plot conspirators, especially during Garnett's own trial. When in moral extremis, the logic went, a person could, consciously and deliberately, use ambivalent words, or 'hold' something back. This offered self-protection or protection of a cause, and was regarded by some theologians as an ethically-defensible position when faced with contradictory

75 See above, pp. 180-181 Bell 16o3, pp. 2-3.

76 Quoted in Bell 1603 , p. 54 . The only Hay matching the description that I have been able to locate is John Hay, who became a Jesuit and went to Scotland 1578 . He notes during his time there that Jesuits are being called a new race of persons. Hay to Mercurian, Paris 9 November 1579, quoted in Forbes-Leith 1885, pp. 141-165.

77 Bell 1603, pp. 2, 54, 58 . 
demands for truth-telling and secret-keeping, but Bell and many other contemporaries saw it as the most sinister of practices. He redefines it for his readers 'in plain English' as lying and cogging. ${ }^{78}$ What he is effectively saying here is that the Jesuits' very usage of language - however much they conceal unpleasant realities by ornate Latinate terms like mentalis restrictio - needs demotic translation if it is to be understood and thus repulsed by right-living and right-speaking Englishmen. The subordination of meaning to form is pure casuistry. He eschews all pretension to rhetoric (although, as we have established that in itself is a rhetorical ploy) and is careful to draw attention every so often in his account to the fact that he for one is speaking 'in plaine English' ${ }^{79}$ Bell may not be a particularly profound thinker, but he has caught the flavour of some of the discourses of the day. These moments of his exposition open up the deeper recesses of contemporary thought on what it was to English and indeed what it was to be 'true' and 'plain'. In his shambling and none too sophisticated way, in the very vitriol of his assumptions and judgements, he is pushing towards an essentialist view of national nature, just as some of his polemical predecessors were doing. This English nature, if abandoned either wilfully through malice, or unconsciously through naïveté, left one dispersed amidst a multitude of superficial and perverting forms. By acting 'in a character', the Jesuits acted out of character, their native character at least, which to Bell, was the one that really mattered.

\section{STAGING ENGLISHNESS AND JESUITISM}

The two major dramas of the early 16oos in which English Catholics played a part - the Gunpowder Plot and the Oath of Allegiance controversy - cast a long shadow over all subsequent thinking in their regard. Both, furthermore, could be said to have had prominent Jesuit dimensions. Jesuit confessors were implicated in the first because, although knowing and disapproving of the plans, they were not permitted to break the seal of confession, a right to silence that was savaged in Henry Garnett's 1606 trial. ${ }^{80}$ In the subsequent allegiance dilemma of 1606 onwards, Jesuits in general opposed taking the oath. ${ }^{81}$ Nevertheless, neither controversy gives

\footnotetext{
78 Bell 1603, p. 29.

79 Bell 1603, p. 29; Bell 1604, sig. Aiv ; Bell 16o6, sigs. $\mathrm{Cr}^{\mathrm{r}}, \mathrm{I}^{\mathrm{v}}$.

80 Caraman 1964 provides the most thorough description of this episode.

81 Sommerville 1981 provides the most in-depth account of the controversy surrounding the Oath of Allegiance.
} 
immediate rise to the sort of explicit reflection on Englishness that we have been considering. In the first instance, it could be because the plot was an event that corroborated what had already been said about Popish treachery. It was a manifestation in itself: one did not need to prove anything after it, or convince anyone that there was a serious threat. That the participants in the Oath of Allegiance controversy did not chose to argue in the language of Englishness gives us pause. It becomes understandable when one considers that the authors who, in Johann Sommerville's words, included 'some of the best minds in Europe for a decade' produced works of high theology and political theory, addressed to their fellow polemicists above the heads of the populace, as it were, and thrashing out the question of allegiance in all its dimensions and reverberations. ${ }^{82}$ Unlike the sources already considered, the interventions in this debate lasting from 1606 to 1614 were not formulated as appeals to the true-hearted Englishman, or as direct warnings to him to avoid degeneration from that state. This gives rise to an interesting insight in itself: discourses which give prominent place to the idiom of national identity are more likely to be (relatively) demotic than high-brow.

There is no question but that religious conflict was the chief drama of the era and appropriately enough, one of the most salient texts in the later period is a play, namely the succès de scandale of its day, Thomas Middleton's A Game at Chesse, produced in 1624. This particular drama is, one might even say, the high point in the representation of dichotomous English and Jesuited identities. ${ }^{83}$ Given the prevalence of theatrical motifs throughout this discourse, it is only fitting that the polarised identities should be played out in front of an audience of tens of thousands. In fact, it adds not a little to the interest to say that this was the most watched play of the whole era during the short space of its performance: about a tenth of London's entire population saw it. ${ }^{84}$ One contemporary noted how it was 'followed wth extraordinarie concourse, and frequented by all sorts of people old and younge, rich and poore, masters and servants, papists and puritans' ${ }^{85}$ In many cases, they saw what they wanted to see, and what constant propaganda had prepared them for: the triumph of the

82 Sommerville 1981, p. 372. Contributions to the debate include [James I] 1607; [Persons] 1608; Bellarmine 1608; Andrewes 1609.

83 Figure 2 represents the frontispiece to this work.

84 Corns 1999, 12.

85 Chamberlain to Carleton 21 August, 1624. Quoted in Bald 1929, p. 163. See also Cal of S.P. (Ven.) vol. 18, no. 577 . 
plain-dealing English over the scheming Papist foreigner. They had the thrill of seeing themselves endangered and almost seduced on the stage, but at last win out over their traditional enemy. After nine enormously successful consecutive nights, it was controversially stopped because the Spanish Ambassador complained (in French) that it was against the 'reputation and civility of the English nation'. The King took action and author and actors were themselves called before the Privy Council. ${ }^{86}$

The popularity of the play had much to do with the immediate context, that is to say with Prince Charles' recent unpopular voyage to Spain in the company of the Duke of Buckingham in search of a Spanish bride, the elusive Infanta Maria Anna. This was meant to be the culmination of a rapprochement between the Stuarts and the Spanish Habsburgs that had preoccupied James in his later years. It was also regarded as a possible way of helping to settle the European war, on-going since 1618. But all this was anathema to a certain type of Englishman. One could say that, in some respects, A Game at Chesse harkens back to the writings of some of the Elizabethan writers in its scepticism about high-status diplomatic manoeuvrings and its deliberate rootedness in 'common-man' agendas and principles. The match (and indeed the idea of Catholic-Protestant unity) was 'cross-grained generally unto the inclination of the people of England'. ${ }^{87}$ In any case, the royal tide was turning in their favour, because the marriage negotiation had definitively broken down by the end of 1623 , and Charles came back keen for war. The pro- and anti-war lobbies fought it out in the subsequent 1624 parliament. Middleton's play, it could well be argued, is an example of literary war-mongering. Its themes, however, range beyond the narrowly topical, drawing on more general anti-Spanish prejudice with which many theatre-goers in the Stuart period would have very familiar. The play also exploits, to a quite extreme degree, the antiJesuit animus, by now an engrained groove of thought. Both prejudices had come down to the late Jacobean generation, gaining accretions along the way, and were linked together irrevocably in many minds.

Middleton chose to represent the international scene as a chess board on which was being played a fiercely serious game between the White House, representing England, and the Black, the Jesuited regime of Habsburg Spain. ${ }^{88}$ So much of the literature has fashioned forth 'types'

\footnotetext{
86 A copy of the Ambassador's letter is to be found in Phialas 1954, pp. 389-399. My translation.

87 Warwick 1813, p. 3 .

88 Upon the chess metaphor and violations of the game's rules within the play see Limon 1986, pp. 98-104, 109.
} 
and 'anti-types': the conceit of the game of chess allowed Middleton to characterise players both as individuals and as symbols. The White King is clearly James I; the Black King, Philip IV whilst Charles and the Duke of Buckingham figure as the White Knight and Duke. Count Gondomar, the hated Spanish Ambassador, appears as the villainous Black Knight and Count Olivares, the royal favourite and director of Spanish foreign policy as the Black Duke. ${ }^{89}$ Many of the other pieces, especially the pawns, are principally to be understood symbolically. Interestingly, the sub-plot in which they figure indeed is particularly important in this play, absorbs more textual space and is characterised by some very striking scenes. There are a few particularly identifiable characters among them but the main point about them is that they could be anybody English or Spanish. The battle between the two houses is construed not merely - or primarily - as a grande affaire d'etat in which ordinary people do not matter. Middleton's point is that everyone has their part to play in ensuring that England wins this struggle for itself. ${ }^{90}$

The anti-Catholic animus in this play is based on the assumption that Catholicism, particularly in its 'Jesuited' manifestation, fully identifies with and indeed is behind the policies of Habsburg Spain and that, together, they are inimical to what constitutes Englishness, as mediated through its people and institutions. This is Middleton's purpose in thrusting forward the figure of Ignatius at the very outset, with error at his feet, for it is thanks to him and the 'children of my cunning' that such a game is played out in the first instance. ${ }^{91} \mathrm{He}$ has fathered generations of Spaniards to thwart England. That theirs is pre-eminently a political mission is revealed most strikingly of all by the Black Bishop's Pawn, the archetypal devious Jesuit, who presents a letter from the Assistant Fathers, naming the countries where they have ambitions: Anglica is the first word to emerge in the secret missive which has been written with lemon juice. The Jesuits are utterly at one with the secular Spanish powers in this desire for universal dominion: it is their 'mayne worke, the great Existence / The Hope monarchall'. ${ }^{92}$ Catholics are associated with the wrong kind of

89 Middleton takes some dramatic liberties with the form of a game of chess: Dukes are of course interlopers. For more possible identifications see Bald 1929, p. 11.

90 Notably the White King's Pawn was meant to be Lord Cranfield, the Lord Treasurer. Marotti concludes that the Black Queen's Pawn is Mary Ward, an English nun, who set up the Institute of the Blessed Virgin Mary on the Ignatian model: thus a female Jesuit, in Middleton's view. Marotti 1999, p. 21.

91 Middleton 1929, The Induction, line 54.

92 Middleton 1929, I.1. 327, 315. 
political activism and a very unfortunate type of universalism. This corresponds with the long-held commonplace that Popery was not merely a profession but a central government, acting through national governments. Particularly striking is the Black Knight's depiction of the acquisition of world hegemony. Spain wants to consume other nations as if they were courses in a meal. France, for example, was the lean, Germany the lard, and Venice the gravy. As for England,

Wee count but the White Kingdome [...]

The garden for our Cooke to pick his Sallets' ${ }^{93}$

The Jesuited Spaniards endeavour to achieve global domination through the usual methods of deceit, seduction, craft, and various subtleties in word and deed. The Black Bishop's Pawn, Machiavellian to the core, defends his attempted seduction on the grounds that it too is forwarding the great cause by indirect ways. The end justifies all their means. Generic and crude the characterisations may well be, but this is a good example of the efficacy of popular theatre in feeding off all the conventional stereotypes. The caricatures have been fashioned repeatedly over two to three generations at least so that by now, the audience are within the same intellectual cocoon.

Compared to the colourful, if woefully stereotypical, Spanish personages, the White House appears rather anaemic and pallid: yet in a sense their relative passivity is the whole point: they are emphatically not playing the game in the politique way that their adversaries are. They are characterised by the absence of deceit, disguise, and corruption. This theme is heralded from the start in the familiar equivalence between Englishness and plain dealing.

Plaine-dealing (thus) by wisedomes guide,

Defeats the cheats of Craft and Pride. ${ }^{94}$

Plain dealing is a refusal to 'deal' at all in the wheedling, corrupt manner characteristic of the way the Spaniards are depicted as using throughout. They after all are the ones to refer regularly to 'our practice' and business. ${ }^{95}$ But Middleton was thus facing a problem. The victory of the English side had to be brought about in such a way as to preserve their plainness: they could not resort to any trick or manoeuvre without undermining their own nature. The resultant check-mate by discovery was his solution. It

93 Middleton 1929, V.3. 93-4.

94 Middleton 1929, p. 47.

95 Middleton 1929, I.1.119. 
involved the White Knight bringing the Black Knight and Duke to the confession of their own duplicity: the former affirmed that dissimulation is the 'prime State-Verture' and admitted that their side have always dissembled, upon which he is promptly check-mated. ${ }^{96}$ The English keep distant from the machinations of the game and still triumph. The absence of 'colour' both literally and metaphorically was thus a point in their favour.

There is another plausible reason for the relative dramatic pallor of the White side. Middleton, it would appear, was more concerned with the idea of an attack on things English than on describing Englishness itself. Hence it was appropriate that it be represented by the vulnerable, virginal, but curiously robust and ultimately victorious pieces. Despite his ultimate triumph, the White Knight was in an extremely vulnerable position for much of the play, having being almost entrapped by the other side.

I should transgresse sure,

Were I to change my side, as you have much wrought mee to it. ${ }^{97}$

Charles who, as heir, should have been a national bulwark had revealed a very vacillating dimension of late. The whole drama is overlaid with the metaphors of deformation and seduction: even in his opening speech, Ignatius is made to speak of deflowering truth and goodness. ${ }^{98}$ Nowhere is this made more clear than in the sub-plot, involving the eminently manipulable and manipulative pawns. Dramatically, these types afforded Middleton the flexibility to present threats to the integrity of the faith and to the life of the nation more imaginatively. Much revolves around the fate of one of them: the White Queen's pawn and the attempts against her spiritual and physical integrity by the Black Bishop's Pawn, aided and abetted by the Black Queen's pawn. The attempts on her virtue include seduction under the guise of spiritual direction, and when that comes to nought, through courtly disguise. Each time, she is extricated. ${ }^{99}$ Yet despite her ultimate safety, Middleton does not intend to underplay the fact that there is a serious threat to national integrity, both in its spiritual and physical dimensions, and that this threat is just as much about common man or woman as it is about dynastic shifts on high. There is no room for anyone to be complacent.

96 Middleton 1929, V.3.166.

97 Middleton 1929, V.3.66.

98 Middleton 1929, Induction, ln 10.

99 Middleton 1929, I.1; III.3-IV.1. 
Worryingly, the danger was often unrecognised by those responsible for the House: James, as White King, showed himself blind to it. ${ }^{100}$ Towards the end of the play, addressing her attacker, this wronged Pawn utters the most direct statement of the play, an explicit warning to the audience.

for such a one as you

Is able to deceiue a mightie Audience,

Naye, those you haue seducst if there bee anie

In the Assemblie, if they see what manner

You playe youre Game with me, they cannot loue you. ${ }^{101}$

Just as Copley had called at the turn of the century for the Jesuited to disjesuit themselves so as to become fully English again, so Middleton, in a very different way, was issuing this same appeal to audiences at the Globe. There were Papists, as an observer noted, among them. Dramatised, the choice remained as stark: English or Jesuited but never both. The threat of seduction was represented on a grander scale when the White Queen herself, representing the Church of England, was set upon by the Fat Bishop in the fourth act. The stakes were even higher here, because if she was lost to the enemy, the game was well and truly crippled.

You aimde at no lesse person then the Queene

The glorie of the game if shee were wun

The way were open to the Master Check. ${ }^{102}$

This time the White King does act and rescues his consort, a reassurance to the audience that the King would wake up to danger before it was too late and would preserve the non-Catholic, non-Spanish character of his country.

One thing that the conceit of a chess game allows Middleton to do very well is to show up the ambiguities at the very heart of the English experience. In the play, one moved across the board and was captured; in reallife, one could switch sides wilfully or be passively seduced. The defections he depicts, it may be said at once, are all one way: it is the White pieces who reveal their falsity and move to the other side, the English who are the turn-coats. Naturally, the Black side are active in trying to win over adherents: when the two Houses face each other for the first time in

100 See Middleton 1929, II.2.

101 Middleton 1929, V.2.32. My italics.

102 Middleton 1929, IV.4.77. Limon 1986 p. 102 holds the White Queen to represent Elizabeth I. 
Act III, the Black Bishop looks across at his counterpart and wishes that he were in his diocese and then he would 'soone change his whiteness'. ${ }^{103}$ But the actual defections are not, in reality, due to their activity so much as to the voluntary betrayal of the White traitors. As Jerzy Limon points out, in order to 'make his point clear even to children, Middleton constantly employs the simplest device in drama - his characters revealing their true nature to readers or spectators.' ${ }^{104}$ And true nature is revealed, in this dichromatic play, by 'stripping' off the surface colour to reveal what is beneath. It is entirely of a piece with the rhetoric problematising cosmetics and clothing that we have seen at earlier points in the story.

The most significant defection is that of the White King's Pawn, meant to represent Lionel Cranfield, the Lord Treasurer, who had supported the Spanish match (probably because of the prospect of a large Habsburg dowry) and was opposed to war with Spain, mostly because he knew it would be a financial disaster for the country. However, an appreciation of his prudence does not figure in Middleton's depiction. Instead, Cranfield, by now the first earl of Middlesex, is represented as the archetype of the slippery, disloyal English court politician who never acts in the public interest. He declares his treachery before the Black Knight, by pointing to the disjunction between his external habit and his heart.

You see my outside, you know my heart $\mathrm{K}^{\mathrm{t}}$

Great difference in the colour. ${ }^{105}$

His whiteness - his identity as a loyal Englishman - is merely painted on; the orientation of his heart speaks him to be a Hispanic alien. The disadvantage, as Middleton hastens to remind us, is at once national and personal. It means that he is going to play false in foreign policy: thus his promise that he will 'keepe all Supplies back, both in meanes and men/ That maye raiye agaynst you'. He has also been personally duped. The Black Knight gloats over the fact that he has been doubly fooled '[o]ut of thy Fayth, from thy Alleagance', thus becoming a 'lost Pawne', doomed to perdition. ${ }^{106}$ Middleton does not say what fate is meted out to him there and then, but we do know that another traitor - the White Bishop's

103 Middleton 1929, III.1.282.

104 Limon 1986, p. 105.

105 Middleton 1929, I.1.345. For an alternative and perhaps better version see [Middleton] 1625 , sig. $\mathrm{C}_{3}{ }^{\mathrm{r}}$ : 'You see my outside, but not my heart /Great difference in the colour.'

106 Middleton 1929, I.1.352, 359. 
Pawn - is castrated: Middleton wanting to point out the emasculating effects of going over to the dark side. ${ }^{107}$

The dramatic high point of the work comes in the central confrontation of the two Houses in the third Act, when the King's Pawn's doubledoubling is exposed.

This whitenes uppon him, is but the Leprousie of pure dissumulation.

Sensationally, his upper garment is removed to reveal that he is half black, that, as the Spanish side reveals crowingly, 'his hart, and his Intents, are of our Colour'. This revelation leads the white King to disown him there and then in public. ${ }^{108}$ What this scene shows up so well is the great possibilities that the drama offers to show the kind of things that polemicists have been talking about for years. The fact that a character is partially stripped on stage and nationally repudiated is to declare, in dramatic terms, that any palliation of a national enemy means that one is not fully English at all. ${ }^{109}$ The attention accorded to these ambivalent characters shows an anxiety at the heart of his vision, a belief that the English were not just passive victims, but in some cases actually willing to 'go over' and to fall prey to Hispanic and Jesuit forces. Middleton's solution is that they must be removed, as a canker on the body politic. In this play, the conflict between what it was to be Spanish and to be English was 'played out', and, far from being totally Manichean as its extended chess form might imply, it constantly draws our attention to a more complicated reality. AngloSpanish relations were ultimately not just a black and white conflict: there were various shades of white, and some were less English than others.

\section{Machiavels and Mercuries in The Caroline Era}

One of the clearest statements subsequent to this about the incompatibility of Englishness and Jesuitism is to be found in Henry Burton's The Baiting of the Popes Bull, published in 1627. Throughout his writings, this

107 Middleton 1929, II.1.267-271.

108 Middleton 1929, III.1.295, 297.

109 Another instance of ambiguity is the Fat Bishop. Alone among the pieces, he did not bear a coloured appellation, being supposed to represent Marco Antonio De Dominis, the ex-archbishop of Spalato who had spent the last decade flirting with Roman Catholicism and Anglicanism in a very ambiguous way, so much so that it was pointless to classify him as anything except as a turn-coat. He turns himself over to the black side eventually. Middleton 1929, III.1.329-344. 
independent minister who would become one of the key voices in the opposition to the Arminianism of Archbishop William Laud and indeed of prelacy in general, gave priority to apocalyptic interpretations of the current state of affair. ${ }^{110}$ The Baiting contains some uncomfortable 'home' truths aimed at the royal court (it is dedicated to both Charles and the Duke of Buckingham) and also a specific section in which he appeals directly to English Catholics to declare their colours. This is the twenty-page 'Aduertisement to those my Countrymen whom the Pope calleth his Catholicke sonnes' attached to the end of the pamphlet. The whole text has to be read contextually. The Oath of Allegiance was being urged anew on Roman Catholics and on 30 May 1626, a papal breve of Urban VIII had objected to its form. This is another moment of showdown, a point at which the conflicting nature of their identities is made particularly acute.

Burton urges on them a consciousness of country which should come before all else: 'My natiue brethren Countrymen, or (if you will) Romane Catholickes'. The effect of an address like this is to lay claim on them by virtue of the first; the latter is rather grudging. Being English ought to matter more to them than being Roman. He is goading them to prove themselves true, declaring it his intention to 'assay at least what [...] English spirit is left in you, as not altogether eaten out'. ${ }^{111}$ He expresses both hope and doubt about their capacity for integration, oscillating between confidence that his voice will be heard by 'all' of them and pessimism that it will be heard at all, seeing that they have been so blinded and deafened by their 'obedience' and are in a state of 'benumbednesse'. ${ }^{12}$ Nevertheless, he would not be addressing Catholics in the first place if he believed them to be an entirely lost cause, and it is in this light that we can read his exhortations to them to show themselves to be 'not onely Rationall Creatures, but English-men', indeed 'true hearted English-men'.113 Many English Protestants had long since accepted, in practice, the residuum of Catholics in the country, as long as they were not actively subversive. Burton, however, is adamant that they abandon and abhor the Pope who is 'author and abettor of conspiracies and treasons' as a necessary precondition for their re-admittance into the good graces of the nation. ${ }^{114}$ What Catholics had to

\footnotetext{
110 See, for example, B[urton] (1628). The Seven Vials.

$111 \mathrm{~B}$ [urton] 1627, p. 74.

$112 \mathrm{~B}$ [urton] $1627, \mathrm{p} .74$, gathering $5^{3 \mathrm{r}}$, pp. $23,60,64,74$.

$113 \mathrm{~B}$ [urton] 1627 , gathering $5^{3 \mathrm{r}}, \mathrm{p} .23$.

$114 \mathrm{~B}$ [urton] 1627, pp. 94-95.
} 
do to prove themselves English, according to Burton, was to recognise the importance of historic liberty. It is crucial that they realise that their form of subjection to an outside power cuts them off from the healthy national body. He quotes the twelfth-century chronicler, Alfred of Beverley, to emphasise this point:

Libera gens, cui libera mens, \& libera lingua,

Sed lingua melior, libera [sic].

A Nation free, whose minde, whose tongue is free:

But hand then tongue will better, freer be.

The sense of the second line is a little difficult. ${ }^{115}$ What it seems to mean is that for a people to have a free mind and a free speech, whilst good, is not enough; they also must be free to act. This freedom from subjection will in turn enhance freedom of speech. This quotation, positioned as it is in the Advertisement to Catholics, has a very special resonance for them. They are not to forget that liberty is their defining mark if they are to remain part of the nation at all.

But if Burton still believes that some Roman Catholics can be prevailed upon to bear national sentiments, he affords no possibility of repentance to the Jesuited. They are the absolute renegades. 'I except and exclude the Iesuites from my least hope of perswading them' he declares. To have a 'true English heart in him vn-Iesuited' was with him an axiom of the first order. ${ }^{116}$ His opinions show how little English Protestant views of the Jesuits had evolved since the 1580 s. Whilst mainstream anti-Catholic prejudice fluctuated and was combined with some measure of practical toleration, anti-Jesuitism remained a constant. Although the order, under the generalship of Claudio Acquaviva had accepted the French parlement's condemnation of Juan de Mariana's De rege et regis institutione, and banned the Society from publishing on the subject of papal authority, nothing, it would seem, could reverse their reputation as treacherous, regicidal, and dishonest. ${ }^{117}$ From the secondary dedication to the Duke of Buckingham, Burton wants to leave us in no doubt about two opposing

115 Quoted in B[urton] 1627, pp. 78-79. Beverley wrote a chronicle entitled Annales sive Historia de gestis regum Britanniae in 1143. The second line does not scan: it ought to be a hexameter or pentameter. There is an alternative phrasing which makes more sense. 'Libera gens cui libera mens et libera lingua /Sed lingua melior liberiorque manus'.

116 B[urton] 1627, pp. 4, 60.

117 De Mariana 1599. In 1610, the book was publicly burned in Paris by the executioner. Nelson charts how the Jesuits distanced themselves from the problematic legacy of the text. Nelson c2005, pp. 168-171. 
categories of being: the Englishmen whom he stands for ('As for me, I am an English-man, a free borne subiect, a true louer of my King and Countrey') and the Jesuited who are amputated from the body politic altogether and who ought to be chased out of the country at once. In a way that recalls the polemical writing of the Elizabethan era, his rhetorical persona is very much that of the simple man who finds it his duty to speak up and instruct his superiors: 'shall I bee silent? shall I not speake? shall I not lift vp my voice like a trumpet?' He resorts to the usual tactic of halfapologising for his boldness and expressing his confidence that his Grace will 'pardon a fooles bluntnesse.' Of course, this is mere prevaricating obsequiousness. He really believes that his advice is of sterling worth, and that he is the plain Englishman aware of obvious dangers to which people in higher positions seem oblivious.

He warns Buckingham against the complacent advice of lackeys who 'sow Pillowes vnder your Elbowes'. If anyone tries to prevent his message from reaching its audience, Burton declares that they are either a Jesuit themselves or must have a 'Iesuiticall spirit'. In short, they make it their business to smother the truth. Jesuits are, after all, the 'most exquisite Artists in the science of flattery'. ${ }^{118} \mathrm{He}$ urges upon Buckingham a radical course of action, necessary for national salvation. These Jesuits are wily game-players: they 'play at fast and loose'. The authorities of the country must beat them at their own game. 'How then shall these Proteus-like Foxes be taken? Certainly there is no other way, but to hunt them out with the Kings owne doggs. Your Grace is the great Iusticiarius Forestae. ${ }^{119}$

The reference to the hunt is combined with some other striking images. The identification of the Jesuit(ed) with the figure of the Machiavel has been mentioned before, but not thoroughly investigated. This identification had been building up over the decades, in part due to the historical accident that the works of Machiavelli had become widely available in England from the 1580 os onwards, that is to say at the very moment at which Jesuit presence in the country began to make itself felt. ${ }^{120}$ For Elizabethan and Jacobean dramatists, the Machiavel was the ideal stage villain: a ruthless and sinister figure, a deft user of masks and strategies, and a cynical manipulator of men. He was deeply theatrical by definition, a man who was clever at acting parts. For many Protestant (and some Catholic) polemicists, it was as if the Jesuits were living Machiavels: they

\footnotetext{
$118 \mathrm{~B}$ [urton] 1627, gatherings ${ }^{* * \mathrm{r}},{ }^{* *} 2^{\mathrm{r}}-2^{\mathrm{v}},{ }^{* *} 3^{\mathrm{v}}$.

$119 \mathrm{~B}$ [urton] 1627 , sigs. $\mathrm{a}^{\mathrm{r}}-\mathrm{a2}^{\mathrm{v}}$.

120 Raab 1964, p. 53.
} 
were the stage villains given walk-on parts in English life. For Burton, the main reason why the Jesuits are un-persuadable (and therefore irredeemable) is that the English and Christian spirit in them had given way to the 'pragmaticall, and worse then Machiauellian'. ${ }^{121}$

Burton also compares the Jesuits to 'Mercuries', especially in their infestation of the royal court. Mercury, in early-modern alchemy, was used to transmute base metals into gold, but there is something false, something suspect about the Jesuit transmutation: they are gilding and glossing over real substances. They may have the capacity to charm 'the chiefest' but it is with 'counterfeit adoration'. ${ }^{122}$ Also known as quicksilver, mercury furthermore conjured up the notion of rapid unpredictable changes. As Henrietta Maria had brought Capuchin and Oratorian chaplains in her entourage, the idea of the Jesuits infesting the court was assuredly exaggerated. Nevertheless, she was linked with Jesuitism in the public mind and although Burton avoids mentioning her by name, he undoubtedly has her on his mind. He urges Buckingham to bestir himself and do what he can to purge the court, his own household and the whole nation of these mercurial figures.

Throughout so many of the texts which seek to talk about identity, the notion of 'shaping' and 'fashioning' have been central. In the Baiting, Burton makes a rather extreme case that the Jesuited are not, in fact, real men but 'in mans shape'. They are truly fabricated. It is with perceptible relief that he turns from then to speak to 'men, to English men, to wise men'. ${ }^{123}$ But he cannot stay away from his enemies for long and he proceeds to compare them to modern-day Circes. Just as Circe, the Greek goddess of magic and enchantment, sorcery even, was said to change her enemies into animals, so, with 'their Circean Cup', did the Jesuits 'transforme our English, as Vlisses his men, into Hogges'. The heavily gendered imagery is not accidental. As the female Circe is a danger to the manhood of Ulysses, the courtly Jesuits are an equivalent threat to proper English manhood. Their seduction methods are similar to hers. Circes had used the trap of luxury, providing men with honey, wine and good food: in short, in an English context, the decadent life of the court. The Jesuits' subtle skill is to exploit the worst 'natiue' property of Englishmen, that is their 'itching affection after noueltie and change'. They know their target, know just how to entice. Circe drugs her victims; Burton uses the language

$121 \mathrm{~B}$ [urton] 1627, p. 74.

$122 \mathrm{~B}$ [urton] 1627 , gathering ${ }^{* * \mathrm{r}},{ }^{* *}{ }^{\mathrm{r}}$.

$123 \mathrm{~B}$ [urton] 1627, pp. 75-76. 
of benumbedness, sensual lethargy and torpor to conjure up the danger in which English men (especially the elite) find themselves. ${ }^{124}$

As is habitual in many of the works we have already considered in connection with this theme, there is a significant speculative content to the work, as Burton focused on 'the great if, imagining what would come about if there an invasion by a Catholic prince, and English Catholics en masse betrayed England to Rome and Spain. This is a version of the damno et dedacore theme: the obsession with a great falling-off. The Jesuited heart is by definition Spanish, because for him the Spanish King is always master: behind any scent of a plot there must be 'Iesuiticall Illusions'. According to Burton, commonsense and reason prove that the Englishman is capable of experiencing far greater happiness under the government of a 'natiue King' than under a 'Spanish yoake'. Because, as it is now, the Englishman is free; 'English liberty' is a collocation that sits easily with his thinking. 'And tell me now O yee English Romain Catholickes, do yee enuy the happinesse of the Spanish yoake? Is it so sweete, trow you, to exchange for it your English liberty?'125 This is all conventional material.

But, to further underline his point, he uses a particular argument in which he insists that the Spaniards actually envy the English, and that he has personal knowledge of the fact. When informed 'how free we were in England from such bondage', they 'deepely sighed (as far as they durst) saying, England was happy'. Oh to be in England! His depiction of the Spaniard betrays the same fixation with extremes of class with which we have become familiar in representations of the French. 'How base and wretched is the whole Commonaltie of that Nation, though Natiues!' It is important for his argument that the Spaniards should be seen as slaves in their own country, so they are hardly likely to export anything else. Even the 'monyed man' there has no permission to purchase lands or buy himself good food. Those whom they conquer will feel the brunt of the yoke even worse of course: 'you must not looke [...] to be vsed together so fauorably, as your Don is: For he is Natiue of Spaine: you Aliens'. ${ }^{126}$

He is also extremely insistent that a free way of life is something that even English Catholics participate in, insofar as they are English, and that in no way should they forfeit this for an illusory happiness under Spanish rule. Addressing them directly, he asks them 'what liberty doe not euen

124 B[urton] 1627, pp. 74, 76, 79.

125 B[urton] 1627, sig. a3 ${ }^{\text {r }}$, pp. 6o, 76,78 .

126 B[urton] 1627, pp. 77,78 . 
you yourselues here inioy? wherein are you restrained, vnlesse a little in that wherein it were happy for you [...] I meane your Romish Religion?' He urges them to judge between the slavish condition that even they would have to endure under the Spaniard, and that native condition 'which yee were before, when yee liued like free English men, euery man vnder his owne Vine and vnder his own Figtree'. There is something more Biblical than English about this utopian vision, it must be said, but all this to persuade Papists that it is naïve of them to imagine that they will be 'Magnificoes' or 'Grandees' in a new Hispanic regime, warning them instead that they would be more like 'Grand Deuills'. 'Iesuiticall eloquence' will lead them to their own self-destruction. The fact that the Spaniards have as their motto: 'Amo proditionem, odi Proditorem; I loue the Treason, but hate the Traytor' should be a disincentive to English Papists to consider switching sides. ${ }^{127}$

Trying to convince readers that their self-interest lay in preserving the status quo rather than changing it was a common ploy when addressing Catholics. One element, however, is very distinctively presented and it concerns the matter of legitimate civic insurrection. What Burton has to suggest may even have subversive implications. As far as he is concerned, the fact that the Spanish have not had a major revolt in recent history is not indicative of positive harmony. In reality, the 'Don' is so poor that 'he cannot chuse but bee true'. It is a revealing statement. They do not have rebellions because the 'poore snakes are kept so cold, that they want courage and strength to sting'. This is in direct contrast to an English way of doing things: 'in England it is otherwise'. ${ }^{128}$ There, men who are able to exercise reason and common sense would never have let things come to such a pass. That strikes one as a rather daring statement in 1627, prescient even. There is an uncomfortable message here for the authorities if they wished to take it. The English can choose to be true, but also choose not to be true to the monarch if his actions do not favour liberty.

So this means that, for Burton, if the English did rebel for a reasonable cause, it would mean being true to themselves. That would be legitimate. In other words, allegiance to royalty is conditional on their being able to pursue a free form of life. Fidelity to the King may be one of their best 'natiue properties', but it is qualified by these other statements. ${ }^{129}$ There is a certain gap opening up between loyalty to one's king and loyalty to one's

127 B[urton] 1627, pp. 78-8o.

$128 \mathrm{~B}$ [urton] 1627 , p. 78 .

129 B[urton] 1627, p. 79 . 
country. If one really identifies with the latter, one might have to 'sting' the former. He might need a lesson. There is a message here for the young, fairly inexperienced Charles to whom the work is dedicated. Like some of the other texts we have considered, among them those of Aylmer and Stubbes, this is a piece of writing which seeks to influence the King as to the state of public opinion. Naturally, Burton could not realistically have expected him to read what he had to say, but in writing it, he is contributing to opinion on the issue and helping to form an articulate public space where matters of high political import are discussed.

To cover himself, Burton immediately appeals to two respectable authorities to substantiate his views on the actively free nature of the English people. One is that of Alfred of Beverley previously cited. The other is Henry IV who 'full well knew the humour of the English' and is said to have advised his son on his death-bed 'of English men, so long as the [y] haue wealth and riches, so long shalt thou haue obeysance: but when they be poore, then are they ready to make insurrections at euery motion'. ${ }^{130}$ Their freedom is constituted, in part, by the capacity to rebel. It is as if he is saying to Charles: recognise who you are dealing with, learn who we are as a people, look at historical antecedents, and be aware that the English will defend their liberty actively. Monarchs come and go: they must remain within the tradition of the people if they are to fulfil their duty adequately. That seems to be his point and it is a politically charged one. Again, Burton is posing as another plain man not just offering counsel but laying down a kind of challenge to his social and political superiors. It will be a challenge that will be stated in more purely political terms in the same era, as we shall see in due course. ${ }^{131}$

\section{The Triumph of a StereotyPe}

Every element of the discourse was in place by the time of Charles' disastrous episode in personal rule. To the patina of prejudices and assumptions, nothing especially new was added subsequently, although there were, to be sure, new contexts which called forth strong articulations of the un-Englishness of popery. These contexts included the activities of the heartily-disliked Catholic French Queen, a court which looked increasingly European in style (and therefore papist), cases of high-society

\footnotetext{
$130 \mathrm{~B}$ [urton] 1627, pp. 78, 79.

131 See below pp. 218-225, 262-272.
} 
conversions, and, most of all, Archbishop William Laud's apparently Romanising policy. Although it was something Laud himself would have denied, the mere hint that England was backtracking into old ways provoked predictable reactions, especially when he acceded to the see of Canterbury in $1633 .{ }^{132}$ All the old assumptions and prejudices stood people in good stead: now they had something concrete to protest about. William Prynne, very much Burton's comrade-in-arms throughout the period, was especially notable for the vitriol and persistence of his antiLaudian writings. ${ }^{133}$ Although theology is a large focus, with Prynne, a national consciousness was always very much in the background of whatever he wrote, just as it was there more explicitly in his criticisms of the cultural habits of the elite. ${ }^{134} \mathrm{~A}$ few of his comments in A quench-coale of 1637 are of especial relevance. Boasting of its 'unpolished' quality, he claims to be doing only what a 'plain-dealing English-man' would do, that is defending the established Church of England, and 'without flattery or partiality' exposing the recent attempts to 'usher in Popery by degrees'. More graphically, he refers to the 'blackslidings' to Popery which have 'crept' into the country of late. This is well-worn idiom with which we are well familiar: it could even have been said by Stubbes. But this is not an appeal to fellow countrymen to remain English at heart or to Catholics to rectify their dispositions. Rather it is an appeal to the King himself, to whom he dedicates the work. As with Burton, he could not have expected the royal dedicatee to read it; nevertheless he was exercising his right as common man. Charles is perforce reliant on advice - he 'commonly see[s] with other mens eyes' - what he should do, Prynne seems to be saying, is to see with common men's eyes. ${ }^{135}$ By presenting his case like this, Prynne was, consciously or unconsciously building upon a century-old tradition of setting the plain Englishman in opposition to the crafty Romanist, and using that as a means of telling even the monarch what was best to do. Once again, the monarchy, advised by 'evil' councillors, had to

132 Yet this has to be set alongside Laud's less than favourable views of Catholics and Catholicism. He played a role in hunting out recusants and opposed the Catholic flavour of Henrietta Maria's court. In 1637, he brought about a proclamation against court conversions to Roman Catholicism. His relations with the papal emissary Gregorio Panzani and papal agent George Con were hostile. In 1639 he again published $A$ Relation of the Conference between William Lawd [...] and Mr Fisher, the Jesuite in expanded form which showed hostility to the dogmas or practices of Rome. ODNB.

133 Both Burton and Prynne were on trial before the Start Chamber for sedition in 1637, along with John Bastwick.

134 See above p. 120.

135 [Prynne] 1637, pp. 3-5. 
be instructed in the right. Prynne was styling himself to be both dutiful subject and active citizen.

The anti-Roman animus in the final, catastrophic decade or so of the reign of Charles I did not, of course, disappear although the manifestations of it prove less revealing for us. Three features stand out in service of the grand narrative. The Catholic financial contribution towards the Bishops wars in 1639 and 1640 , limited though it was, and the machinations of Henrietta Maria's court circle to secure papal and French support for Charles did little for the national credibility of any of them. ${ }^{136}$ The Irish rebellion in the autumn of 1641 , and its lurid representation in John Temple's account somewhat later as a murderous plot to extirpate all English Protestants, lent direct proof to those who those whose vision was already defined by anti-Romanism. ${ }^{137}$ The recruitment of papists in the royalist armies brought the threat ever closer, and Charles was, at the very least, tarnished by association, seen as being caught up in a popish plot which would destroy the whole country.

With all this in the air, the early 1640 s would appear to be a prime place for the sort of reflections with which we have been concerned. Yet there is little of it to be found in the panic-driven literature of that time. The initial climate of terror, so well described by Robin Clifton, was conducive to hysteria more than anything, and what we expect and indeed find is the prevalence of an apocalyptic tone which offers prophecies more than observations. Consequently, although the link between Popery and arbitrary tyranny was often reaffirmed, and the danger of both to England stated on multiple occasions, there is less considered reflection about what it meant to be English in this context. All the fierce dichotomies of the discourse are regurgitated but nothing particularly new emerges. One could say that the logic of this discourse plays itself out fully in the cries of grand conspiracy, roused and orchestrated principally by John Pym, outstandingly at the beginning of the Long Parliament. ${ }^{138}$ Religion was the first of his heads of grievances in his memorable speech of 7 November 1640, and he outlines three predictable culprits: the 'Papists party' who sought to alter national religion, the Church of England clergy who are, he argues, edging for union with Rome, and most importantly, the devious

136 Albion 1935; Hibbard 1983; White 2006.

137 Temple 1646.

138 In the Short Parliament, Pym's 17 April speech had announced religious innovations as the second of his grievances Kenyon 1966, pp. 198-200. 
agents for 'Spain and other kingdoms'. ${ }^{139}$ The nature of Pym's national construction against Popery is by now generic but not the less potent for that: it has soaked up so much cultural resonance since the early days of Elizabeth's reign. People know exactly what he means when he refers to such subversive 'agents'.

Furthermore, Pym exploited the revelations about an army plot in May 1641 to bolster the idea of a full-scale popish plot and the subsequent Oath of Association which all MPs were required to take committed them to maintaining and defending the church 'against all Popery and Popish innovation within this realm' and expressed the conviction that the 'designs of the priests and Jesuits, and other adherents of the see of Rome' were behind the recent endeavours to subvert the law of the land and to 'introduce the exercise of an arbitrary and tyrannical government'. ${ }^{140}$ The Grand Remonstrance itself, later that same year, was premised on the principle that, as 'loyal subjects', they could not endure the growing influence of 'malignant parties' who 'set up and acted by the subtle practice of the Jesuits and other engineers and factors for Rome'. ${ }^{141}$ This is staple reactionary fare and a repetition of themes that have long been worked over. The same goes for the rest of Pym's contribution to the antiCatholicism of this period: the motif is deeply embedded but he does not intellectualise it. ${ }^{142}$

What is happening in the 1640 is the acting out of this century's old prejudice. The mere rumour of popish plotting was enough to cause panics and riots especially in cities during the years 1640 to 1642 , but this, although it resulted in physical violence, would not appear to have led to sustained reflection on what it signified or was supposed to achieve. ${ }^{143}$ Then there was the apocalyptic strain of thinking which received a whole new lease of life in the disturbing circumstances of civil war. In this narrative, Rome had its established place. ${ }^{144}$ But now Rome itself had many

139 Kenyon 1966, p. 204.

140 Kenyon 1966, pp. 222-223.

141 Kenyon 1966, p. 299.

142 Consider, for example, Pym 1641a; Pym 1641b; Pym 1641c.

143 Clifton 1971, pp. 25-33. He notes (p. 32) that the panics came to a halt after 1642 once the war began, and this 'despite the confusion and defeats of war, the open presence of Catholics in the royalists' army, Charles's negotiations to add Irishmen to his forces, and the most strenuous efforts of Catholic-baiting parliamentary propagandists'. He is puzzled by this, but notes (pp. 41-42) that there were pressing economic factors in 1640-2 which accounted for an upsurge in the popular animus against Catholics, and also that the war showed their weakness as a force.

144 Christianson 1978 takes the apocalyptic strain in Protestant thinking from Reformation to the eve of the Civil War. For an account of apocalyptic thinking until 1645 see Firth 1975; also Hill 1990. 
more contenders for the attribution of Babylon: there were a host of potential players, depending on what side one took. In many cases, religious or quasi-religious writings which are more concerned with proving a spiritual case do not yield considerations of what made the Englishman true. Furthermore, there was a sense in which the phenomenon of popery had picked up so many resonances in an English context, had become identified with so many things that people held to be inimical, that it was, if not meaninglessly applied in the 1640 s, at least so loose a term as to be able to serve as a kind of random accusation of any group that went against one's own beliefs of policies. And so, practically all groups, as Clifton notes, were imputed to be papist at some point - Presbyterians, Baptists, Quakers, Brownists, Familists, Seekers, Anabaptists, and Ranters, not to speak of the royalists themselves. ${ }^{145}$ For this, various reasons could be cited, from sedition and treasonable instincts, to unscriptural beliefs and immoral practices. This looseness of ascription is indicative in itself. Anyone whose national credentials were in doubt was, for the time being at least, considered Popish. That, in itself, attests not only to the power of the construction but also to its considerable plasticity. Romanism meant everything that many Englishmen thought they were not. But if this discourse becomes hopelessly vague in the 1640 , it was the moment of maturity for other, more purely political discourses about what it was to be English. It is (however sloppily) taken for granted in mainstream polemic that the true Englishman is not Popish and especially not Jesuited by the end of the period. But what sort of creature ought he be, politically? For that, we must backtrack.

145 Clifton 1971, p. 33, n. 56. 